\title{
Comparative susceptibility and histopathology of the response of naive Atlantic, chinook and coho salmon to experimental infection with Lepeophtheirus salmonis (Copepoda: Caligidae)
}

\author{
S. C. Johnson ${ }^{1, *}$, L. J. Albright ${ }^{2}$ \\ ${ }^{1}$ Department of Fisheries and Oceans, Biological Sciences Branch, Pacific Biological Station, Nanaimo, British Columbia, \\ Canada V9R 5K6 \\ ${ }^{2}$ Institute for Aquaculture Research, Simon Fraser University, Burnaby, British Columbia, Canada V5A 1S6
}

\begin{abstract}
The comparative susceptibility of naive Atlantic Salmo salar, chinook Oncorhynchus tshawytscha and coho Oncorhynchus kisutch salmon to infection with the economically important marine ectoparasitic copepod Lepeophtheirus salmonis was investigated under laboratory conditions. Coho salmon were the most resistant to infection followed by chinook then Atlantic salmon. Copepods were lost from the gills of coho salmon by $10 \mathrm{~d}$ post-infection and only a few remained on the fins at $20 \mathrm{~d}$ post-infection. Although their abundance declined significantly, copepods were retained on both the gills and fins of chinook and Atlantic salmon over the $20 \mathrm{~d}$ studied. Rejection of $L$. salmonis on all 3 host species appears to be due to non-specific host responses. Histological sections of coho fins and gills revealed well-developed epithelial hyperplasias and inflammatory responses to the presence of L. salmonis. Gill and fin tissue responses of chinook salmon to L. salmonis appeared to be intermediate in intensity between those of coho and Atlantic salmon. Only minor gill and fin tissue response to the presence of $L$. salmonis was observed in Atlantic salmon.
\end{abstract}

\section{INTRODUCTION}

Lepeophtheirus salmonis is a common marine ectoparasitic copepod of wild and sea-farmed salmonids including: Oncorhynchus clarki (= Salmo clarki) (coastal cutthroat trout), Oncorhynchus gorbuscha (pink. salmon), Oncorhynchus keta (chum salmon), Oncorhynchus kisutch (coho salmon), Oncorhynchus mykiss (= Salmo gairdnen) (rainbow or steelhead trout), Oncorhynchus nerka (sockeye salmon), Oncorhynchus tshawytscha (chinook salmon), Salvelinus fontinalis (brook trout), and Salmo salar (Atlantic salmon) in the northern hemisphere (Kabata 1979, 1988, Wootten et al. 1982 Pike 1989).

This species has a direct life cycle consisting of 5 phases and 10 stages. These include 2 free-swimming

- Addressee for correspondence naupliar stages, 1 free-swimming infectious copepodid stage, 4 attached chalimus stages, 2 preadult stages, and an adult stage (Johnson \& Albright 1991a). Attached copepodids, chalimus larvae, preadults and adults feed on host mucus, skin and blood (Kabata 1974, Brandal et al. 1976).

When abundant, Lepeophtheirus salmonis causes serious disease characterized by extensive areas of skin erosion and hemorrhaging on the head and back, and a distinct area of erosion and sub-epidermal hemorrhages in the perianal region (Brandal \& Egidius 1979, Wootten et al. 1982). In wild salmonid stocks serious disease caused by $L$. salmonis has been rarely reported. However, in sea-farmed salmonids, major epizootics of this parasite commonly occur, resulting in serious disease and high levels of mortality if untreated (Brandal \& Egidius 1979, Wootten et al. 1982).

Differences in the prevalence and abundance of Lepeophtheirus salmonis among salmonid species have 
been reported. Nagasawa (1987) reported for high-seas salmonids caught in the central North Pacific Ocean that chinook salmon are the most heavily infected followed in descending order by steelhead trout, pink salmon, chum salmon, coho salmon and sockeye salmon. Nagasawa et al. (1991) reported for high-seas salmonids caught in the northern North Pacific Ocean and the Bering Sea that pink salmon were the most frequently and heavily infected species followed in descending order by steelhead trout, chinook salmon, coho salmon, chum salmon and sockeye salmon. In British Columbia, Canada, sea-farmed Atlantic salmon are generally more heavily infected with $L$. salmonis than chinook or coho salmon raised at the same site (pers, obs.).

Differences in the level of infection between salmonid species is commonly believed to be due to differences in their behaviors. Nagasawa et al. (1991) suggest that differences in the level of infection may be related to differences in swimming speed, depth distribution, or differences in the structure of the skin resulting in differential suitability of the skin as a site of infection. To date no experimental work has been conducted to determine other factors that may explain these differences.

The objective of this study was to determine if there are differences in the susceptibility of naive Atlantic, chinook and coho salmon to infection with Lepeophtheirus salmonis under controlled laboratory conditions. The histopathology of attachment and feeding sites is described using light microscopy.

\section{MATERIALS AND METHODS}

Ovigerous Lepeophtheirus salmonis were collected from sea-farmed Atlantic salmon Salmo salar from Departure Bay on the east coast of Vancouver Island, Canada. The eggs were hatched and the larvae reared to the infectious copepodid stage at 9 to $10^{\circ} \mathrm{C}$ following the methods outlined in Johnson \& Albright (1991b).

Naive Atlantic, chinook and coho salmon (36 each), ranging in size from 15.2 to $22.6 \mathrm{~cm}$ in length, were introduced into a $500 \mathrm{l}$ tank, acclimated for $1 \mathrm{wk}$, and then exposed for 24 h to ca 3000 newly molted copepodid larvae. These salmon had been smolted and reared in sand-filtered seawater to ensure no previous exposure to Lepeophtheirus salmonis. The infection was carried out under conditions of darkness, low water flow, and aeration. A large surface area screen with $180 \mu \mathrm{m}$ mesh size was used to prevent copepodid loss during the infection. After exposure the screen was removed and the water flow increased. The fish were maintained in flowing filtered seawater with a temperature of 9.3 to $10.2^{\circ} \mathrm{C}$ (mean $9.6^{\circ} \mathrm{C}$ ) and ambi- ent salinity 29 to $31 \%$. Five of each fish species were killed at $1,3,5,10,15$ and $20 \mathrm{~d}$ post-infection with an overdose of the anesthetic MS-222 (tricaine methanesulfonatel The fork length and wet weight were determined for each fish. Both the anesthetic bath and the body surfaces were examined for copepods and the distribution of the copepods on the fish was noted. The total number of copepods recovered was corrected to a standard fish wet body weight to compensate for differences in size among hosts.

Intensity data were $\log (x+1)$ transformed and differences in copepod intensity investigated by analysis of variance (ANOVA) procedures. Multiple comparisons of copepod intensity for each host species over time, and between host species at each sampling period, were made using Scheffé's tests (Zar 1984).

Tissues for examination by light microscopy were fixed in Davidson's solution and dehydrated through to $100 \%$ alcohol. Tissues were either wax-embedded, cut to a thickness of $5 \mu \mathrm{m}$ and stained with hematoxlylin and eosin, or they were embedded in JB4 plastic resin, cut to a thickness of 1 to $2 \mu \mathrm{m}$ and stained with Lee's stain (methylene blue and basic fuschin)

\section{RESULTS}

\section{Intensity of infection}

The intensity of Lepeophtheirus salmonis on naive Atlantic, coho, and chinook salmon over time is presented in Fig. 1. The intensity of infection for each host species was significantly different over time (1-way ANOVA; Atlantic salmon: $p<0.01$; coho salmon: $p<0.001$; chinook salmon: $p<0.01$ ). The results of multiple range tests (Scheffé's test; $p<0.05$ ) over time showed both Atlantic and chinook salmon had significantly fewer copepods at 10 and 20 d post-infection when compared to $1 \mathrm{~d}$ post-infection, and coho salmon had significantly fewer copepods at 15 and $20 \mathrm{~d}$ postinfection when compared to $1,3,5$ and $10 \mathrm{~d}$ postinfection

There was no significant difference in copepod intensity between host species at 1,3 and $10 \mathrm{~d}$ postinfection (Scheffé's test; $\mathrm{p}<0.05$ ). At $5 \mathrm{~d}$ post-infection there were significantly fewer copepods present on coho salmon than on Atlantic salmon, and no significant difference in copepod intensity between Atlantic and chinook salmon (Scheffé's test; $p<0.05$ ). At 15 and $20 \mathrm{~d}$ post-infection there were significantly fewer copepods present on coho salmon when compared to both Atlantic and chinook salmon, and no significant difference in copepod intensity between Atlantic and chinook salmon (Scheffé's test; $p<0.05$ ) 


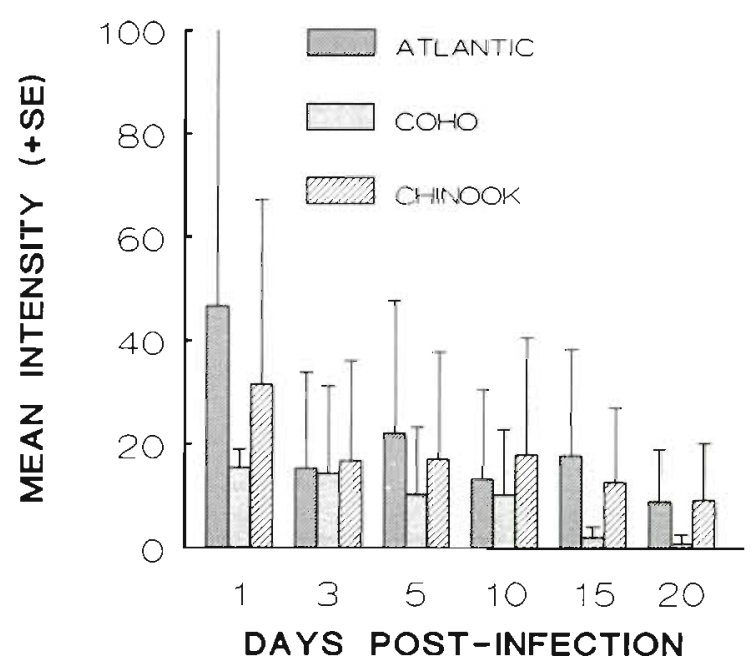

Fig. 1. Lepeophtheirus salmonis infecting Salmo salar, Oncorhynchus tshawytscha and $O$. kisutch. Mean (+SE) intensity of copepods on naive Atlantic, coho, and chinook salmon at various times post-infection. Salmon were maintained at 9.3 to $10.2^{\circ} \mathrm{C}$ and ambient salinity (29 to $31 \%$ )

\section{Distribution on hosts}

At 1 d post-infection approximately equal percentages of the copepods recovered from coho were from the anesthetic bath and the fins (Fig. 2). The percentage of copepods found in the anesthetic bath decreased from ca $38 \%$ to $0 \%$ by $15 \mathrm{~d}$ post-infection. Of the copepods attached to the fish, the highest percentage was on the fins at each sampling time. The percentage of copepods on the gills decreased from

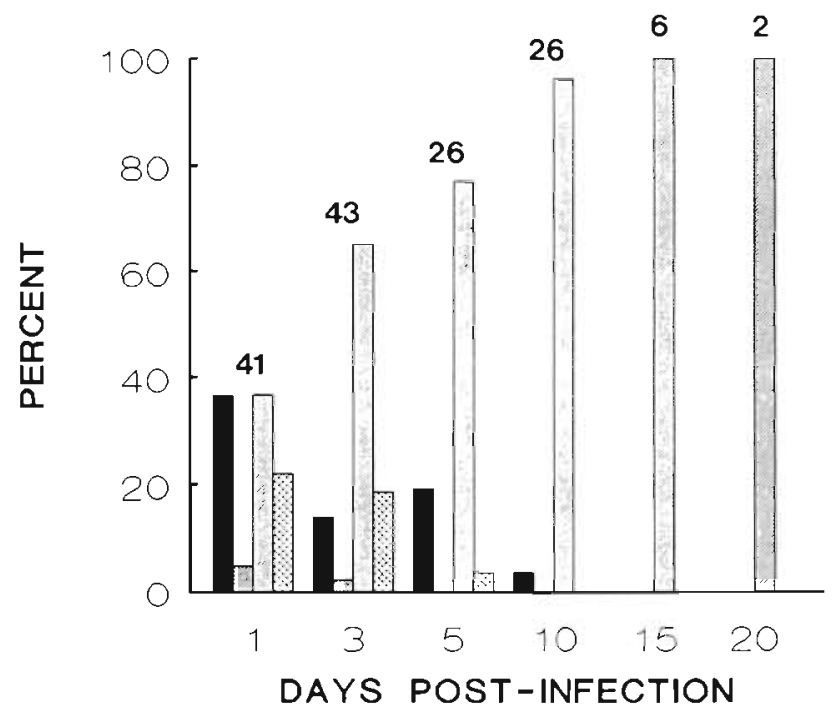

Fig. 2. Lepeophtheirus salmonis infecting Oncorhynchus kisutch. Distribution of copepods on naive coho salmon. Values above bars are the total number of copepods collected. Conditions as in Fig. 1; see Fig. 3 for explanation of shading ca $22 \%$ to $0 \%$ by $10 \mathrm{~d}$ post-infection. A low percentage of copepods was found on the general body surfaces, including surfaces of the buccal cavity and mouth, at both 1 and $3 \mathrm{~d}$ post-infection.

At $1 \mathrm{~d}$ post-infection the highest percentage of copepods recovered from Atlantic salmon was from the anesthetic bath (Fig. 3). This had declined to $0 \%$ by $15 \mathrm{~d}$ post-infection. Of the copepods attached to the fish, the highest percentage was on the gills at 1, 3 and $5 \mathrm{~d}$ post-infection, and on the fins at 10,15 and $20 \mathrm{~d}$ post-infection. The percentage of copepods on the body was low throughout the experiment, increasing slightly at $20 \mathrm{~d}$ post-infection with molting to the preadult stage.

At $1 \mathrm{~d}$ post-infection the highest percentage of copepods recovered from chinook salmon was from the anesthetic bath (Fig. 4). This percentage had declined to $0 \%$ by $15 \mathrm{~d}$ post-infection. Of the copepods attached to the fish, the highest percentage was recovered from the fins, then from the gills, and then from the general body surfaces at all sampling times.

Copepods were recovered from all gill arches of the host species. With exception of a few, all were attached to the distal half of the gill filaments, with the majority attached to the filament tips. Of the copepods recovered from the fins of coho salmon the majority were on the pectoral $(33 \%)$ and pelvic $(31 \%)$ fins. Of those recovered from the fins of Atlantic salmon the majority were on the caudal (28\%), pelvic ( $26 \%$ ), and pectoral $(25 \%)$ fins. With exception of the adipose fin, copepods were distributed almost equally among the fins of chinook salmon (pectoral: $25 \%$; pelvic, anal, dorsal and caudal: 18 to $19 \%$ ).

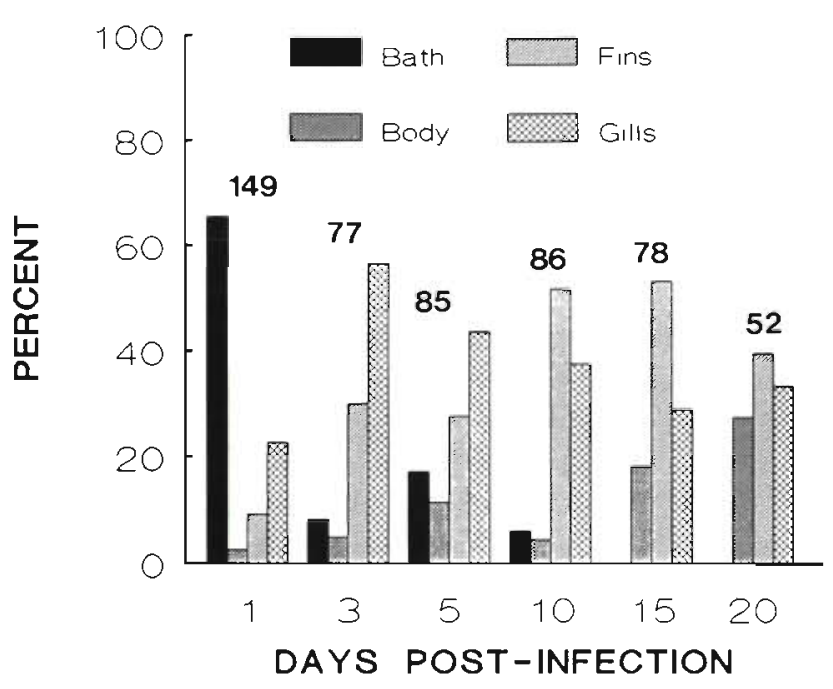

Fig. 3. Lepeophtheirus salmonis infecting Salmo salar. Distribution of copepods on naive Atlantic salmon. Values above bars are the total number of copepods collected. Conditions as in Fig. 1 


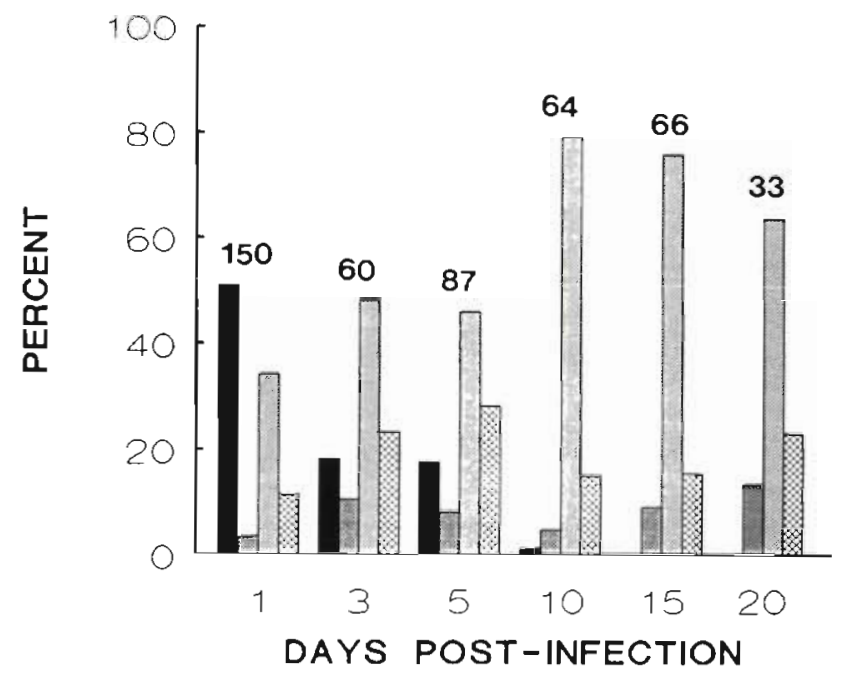

Fig. 4. Lepeophtheirus salmonis infecting Oncorhynchus tshawytscha. Distribution of copepods on naive chinook salmon. Values above bars are the total number of copepods collected. Conditions as in Fig. 1; shading as in Fig. 3

\section{Copepod developmental stages}

The percentages of each developmental stage of Lepeophtheirus salmonis present at $20 \mathrm{~d}$ post-infection on both Atlantic and chinook salmon are presented in Fig. 5. Of the 47 copepods recovered from Atlantic salmon the greatest proportion were late third chalimus larvae, followed by first preadult males then first

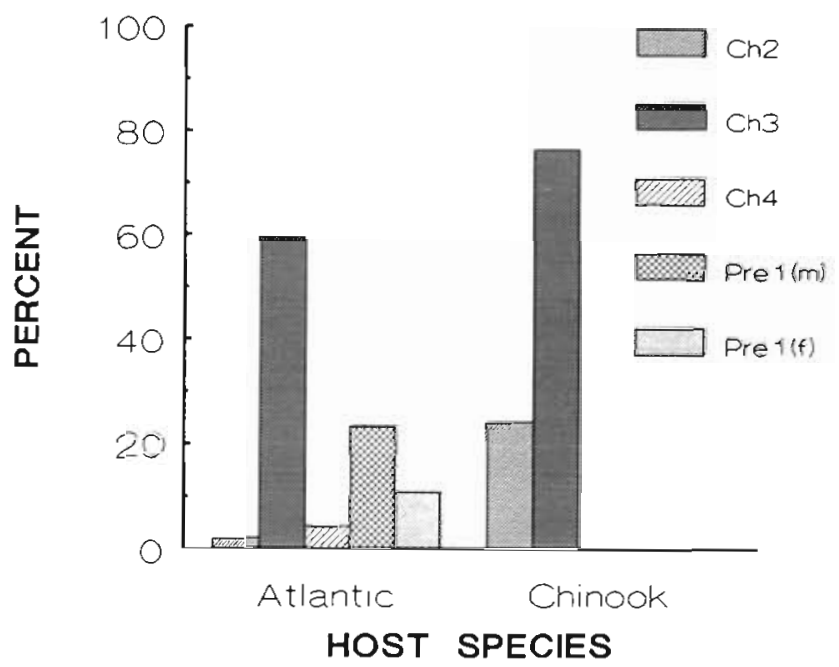

Fig 5. Lepeophtheirus salmonis infecting Salmo salar and Oncorhynchus tshawytscha. Developmental stages of copepods present on naive Atlantic and chinook salmon at $20 \mathrm{~d}$ post-infection. Percentages based on 33 copepods collected from Atlantic salmon and 52 copepods collected from chinook salmon. Ch2: second chalimus; Ch3: third chalimus; Ch4: fourth chalimus; Pre1(m): first preadult male; Pre1(f): first preadult female. Conditions as in Fig. 1 preadult females. Of the 25 copepods recovered from chinook salmon all were either second or third chalimus larvae.

The percentage of each developmental stage of Lepeophtheirus salmonis present on the different body regions of Atlantic salmon at $20 \mathrm{~d}$ post-infection are presented in Fig. 6 . Of the 11 copepods recovered from the gills, all were late third chalimus larvae. Ot the 21 copepods recovered from the fins, the greatest proportion were late third chalimus larvae, followed by attached first preadult males, fourth chalimus larvae and attached first preadult females. Of the 15 copepods recovered from the body, the greatest proportion were late third chalimus larvae followed by unattached first preadult males then unattached first preadult females

\section{Histology of gills}

At 1, 3 and $5 \mathrm{~d}$ post-infection, attachment and feeding sites on gills of coho salmon were characterized by partial to complete erosion of the epithelium, minor hemorrhaging, and acute inflammation (Fig. 7A, B). The inflammatory infiltrate consisted primarily of neutrophils, but lymphocytes were also present. In some sections mild epidermal hyperplasia occurred at the tips of the lamellae.

At 1, 3 and 5 d post-infection, attachment and feeding sites on gills of both Atlantic and chinook salmon were characterized by variable amounts of erosion of the epithelium, small amounts of hemorrhage, and mild inflammation (Fig. 7C, D). The inflammatory

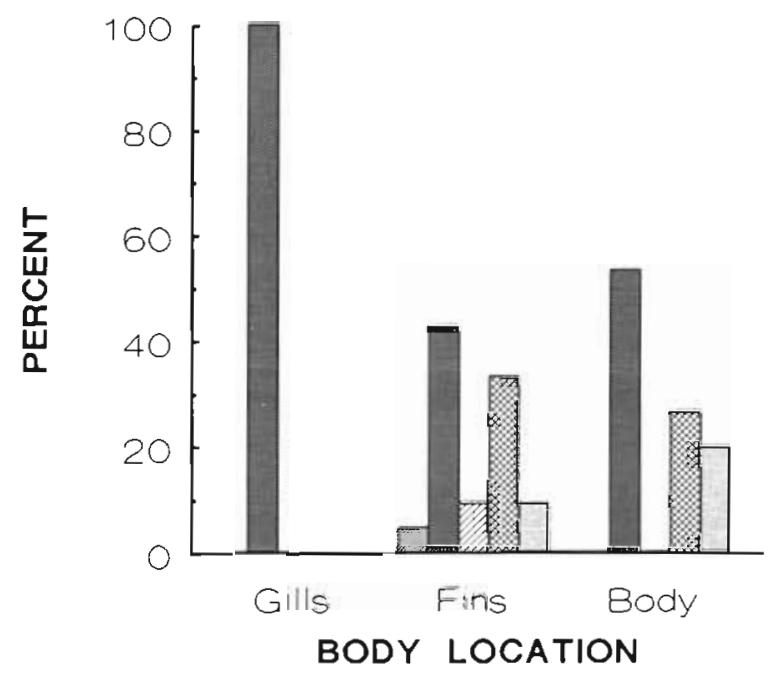

Fig. 6. Lepeophtheirus salmonis infecting Salmo salar. Developmental stages of copepods present on different body regions of naive Atlantic salmon at $20 \mathrm{~d}$ post-infection. Percentages based on 33 copepods. Conditions as in Fig. $1_{i}$ shading as in

Fig. 5 


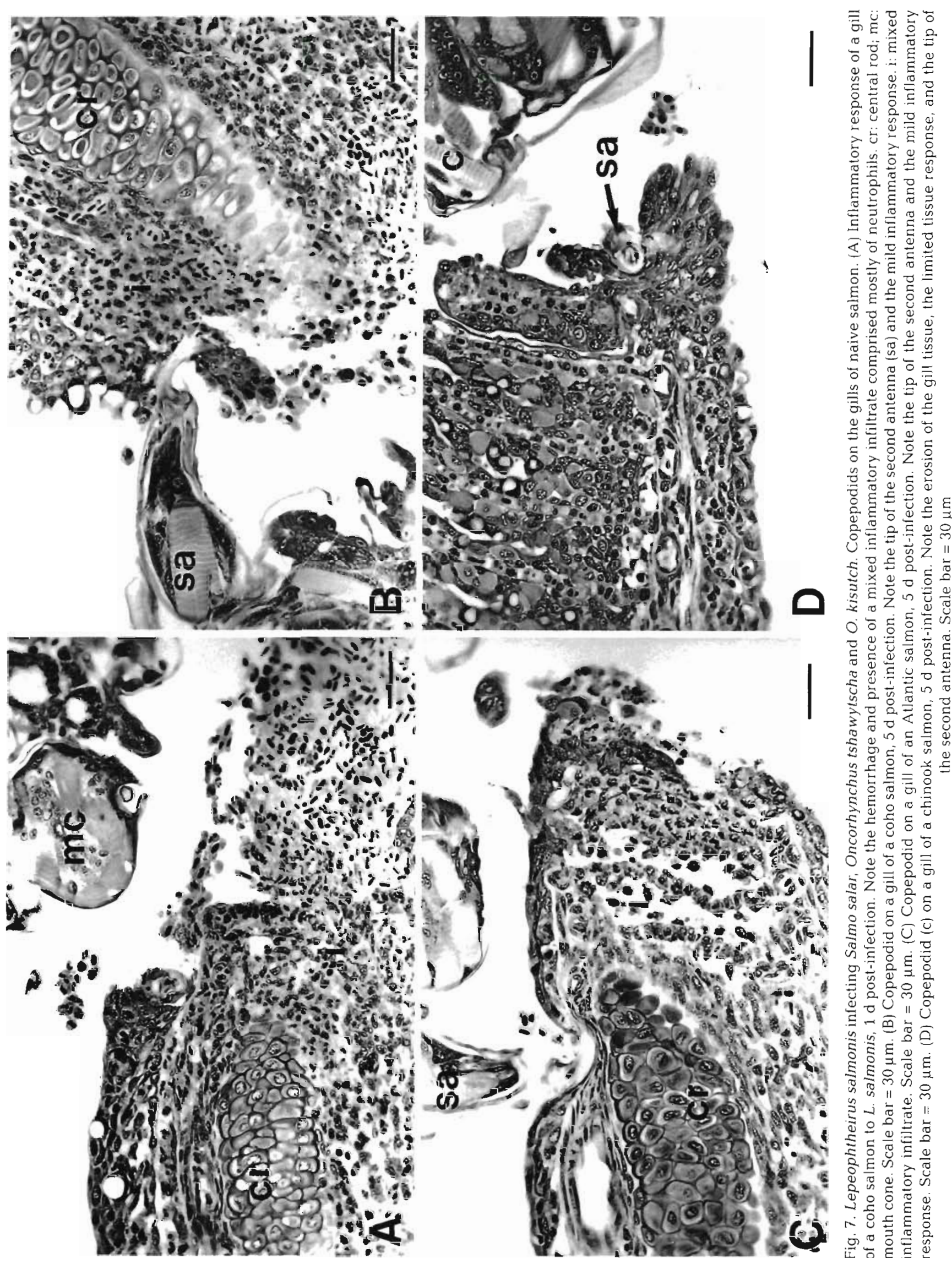




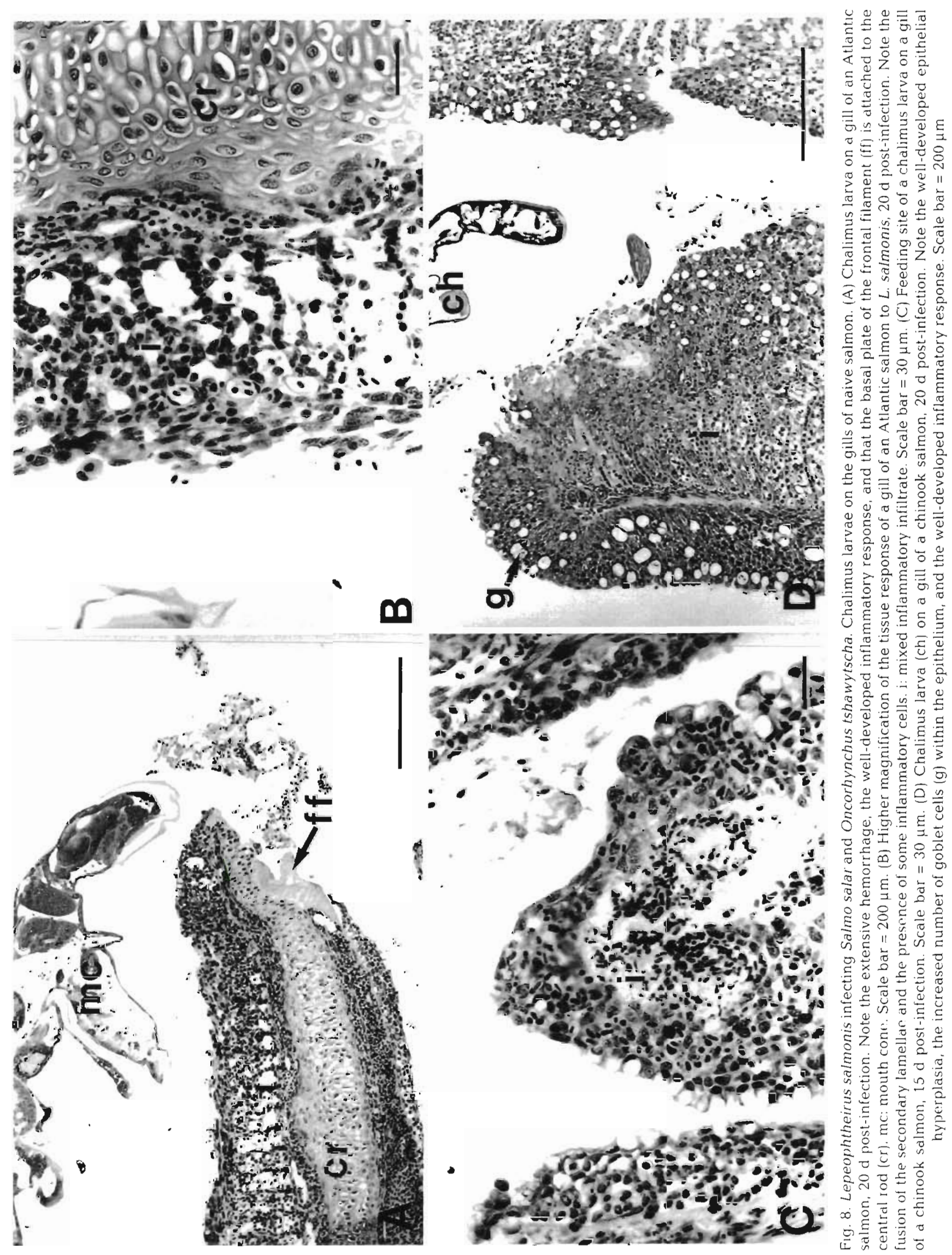


infiltrate consisted of abundant neutrophils and a few lymphocytes. In a portion of samples collected at $5 \mathrm{~d}$ post-infection the cartilaginous central rods of the filaments were exposed.

Gross examination of the gills of both Atlantic and chinook salmon at 10,15 and 20 d post-infection revealed distinct crypting (atrophy and disappearance of the distal portions of the lamellae) and fusion of the secondary gill lamellae in the vicinity of the copepods. At $10 \mathrm{~d}$ post-infection, histological examination of the gills of both species revealed variable amounts of epithelial erosion, some hemorrhage, mild inflammation, some epithelial hyperplasia, and the fusion of secondary gill lamellae. The extent of these changes as well as the number of primary lamellae affected increased in both species at 15 and $20 \mathrm{~d}$ post-infection (Fig. 8A to D). From $10 \mathrm{~d}$ post-infection onwards there was a proliferation of goblet cells within the hyperplastic epithelium of the chinook salmon gills (Fig. 8D). No proliferation of goblet cells was evident in the hyperplastic epithelium of the Atlantic salmon gills. The inflammatory infiltrate of both species consisted primarily of neutrophils, but a few lymphocytes were also present. In general, the intensity of the response of the gills to the presence of Lepeophtheirus salmonis was greater in chinook than Atlantic salmon. In both species secondary infection of the gill lesions by rodshaped and filamentous bacteria occurred at 15 and $20 \mathrm{~d}$ post-infection.

\section{Histology of fins}

At 1,3 and $5 \mathrm{~d}$ post-infection, attachment and feeding sites on fins of all 3 host species were characterized by partial to complete erosion of the epidermis (Fig. 9A to D). Over this period the severity of the lesions was highly variable both between and within host species, with later lesions not necessarily more severe than earlier lesions. Mild inflammation of the dermis occurred in coho salmon as early as $1 \mathrm{~d}$ post-infection (Fig. 9A, B). Neutrophils were the predominant cells at these sites of inflammation, but lymphocytes were also present. No inflammatory responses were observed in either the Atlantic or chinook salmon over the same period (Fig. 9C, D).

At 10,15 and $20 \mathrm{~d}$ post-infection, attachment and feeding sites on fins of coho salmon were characterized by well-developed epithelial hyperplasias, which in severe cases resulted in complete encapsulation of the copepods (Fig. 10A). In cases of partial or complete encapsulation the spaces surrounding the copepod were filled with tissue debris and a mixed inflammatory infiltrate (neutrophils, macrophages and a few lymphocytes) (Fig. 10B). Lesions at the point of feeding commonly extend through to the dermis exposing the fin rays. Necrotic tissue, some hemorrhage, and welldeveloped inflammation of the dermis occurred at these sites. The inflammatory infiltrate consisted of abundant neutrophils, some macrophages, and a few lymphocytes.

At 10,15 and $20 \mathrm{~d}$ post-infection, attachment and feeding sites on fins of both Atlantic and chinook salmon showed little tissue response to the presence of the copepods (Figs. 10C, D \& 11A, B). At the point of feeding the epidermis was commonly breached and the underlying dermis and fin rays exposed to the external environment. In some sections mild inflammation of the dermis was evident. The inflammatory infiltrate consisted of abundant neutrophils and a few lymphocytes. In both species, secondary infection of the fin lesions by rod-shaped and filamentous bacteria occurred in some of the samples collected at 15 and $20 \mathrm{~d}$ post-infection.

\section{Histology of frontal filament}

Chalimus larvae and some first preadult males and females are attached to their hosts by frontal filaments. The frontal filament consists of an elongate stem and a basal plate (Fig. 12A). In section the stem appears to consist of 2 regions. The outer region has similar staining characteristics to that of the body cuticle and appears to be continuous with it. The inner region appears fibrous and has a duct-like structure (axial duct) running along its length. The basal plate stains darker than both layers of the stem. Basal plates are most commonly attached to the cartilaginous central rods of the primary gill lamellae or to the fin rays (Fig. 10C). Less commonly, basal plates are attached to the basement membranes of the gills and fins

Within the anterior cephalothorax of late copepodid and chalimus larvae, materials with similar staining characteristics to those of the frontal filaments were commonly observed (Fig. 9D). Fully formed frontal filaments (stem and basal plates) were found in the anterior cephalothorax of 2 chalimus larvae which were in the process of molting (Fig. 12B). These filaments had similar staining characteristics to attached filaments, but differed in the structure of their stems. In both instances the inner region of the stems appeared to consist of distinct fibrous bands interspersed with small amounts of living tissue. The invaginations of the anterior cephalothorax which surrounded the new filaments were lined with newly formed external cuticle, which appeared to be continuous with the stems (Fig. 12B). Old filaments were attached to and are apparently lost with the molted exoskeletons. 


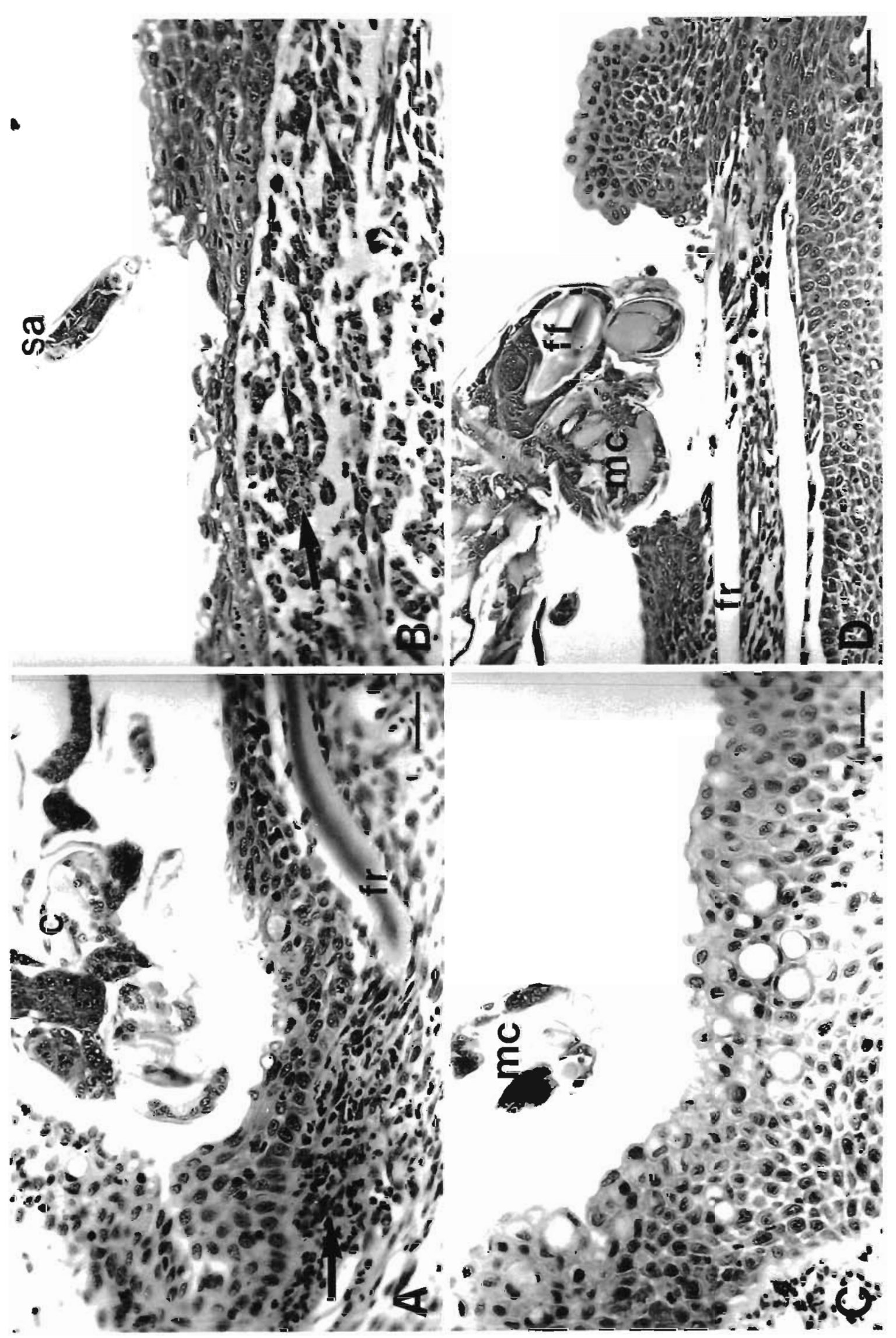

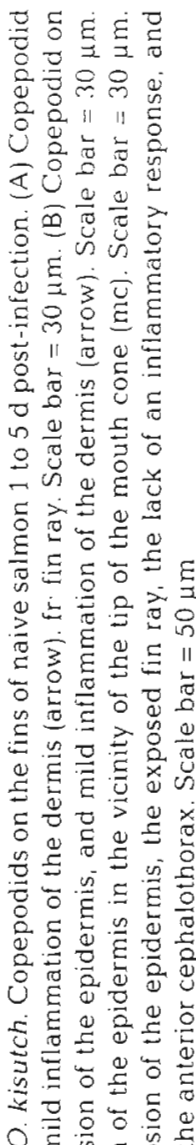

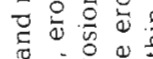

है

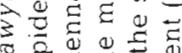

的。

ज० $\bar{~}$

政

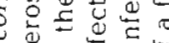

๑ $\leqq$

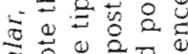

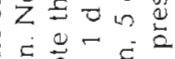

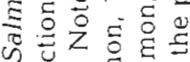

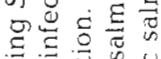

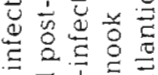

รㄴ.

s

的巨品

Q

일

잉

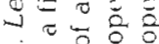

5 50 

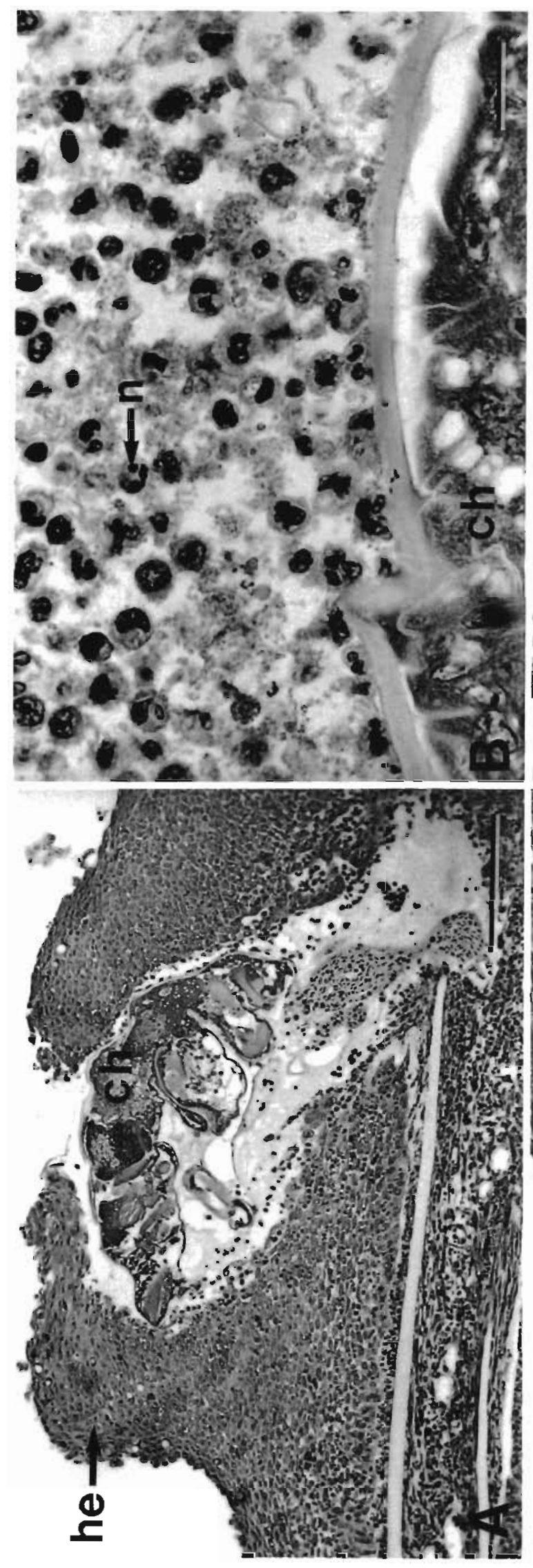

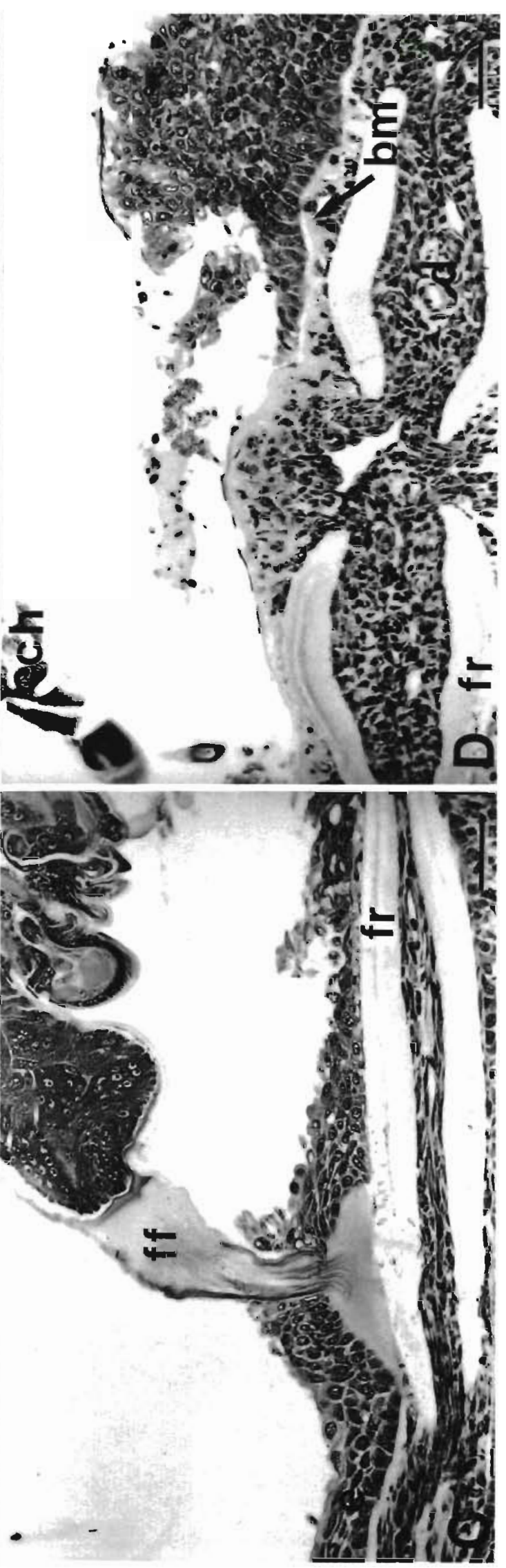

¿ำ

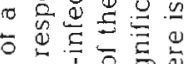

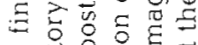
0 응

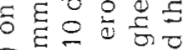

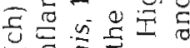
政 政

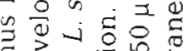

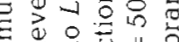

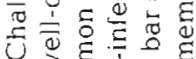

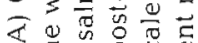
$\div$ 의 용요 品它爷 ४ $\Xi \Xi \Xi 5$

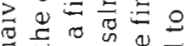
ธथ 0.

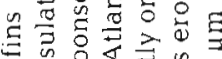

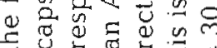
동 云它它 षे ธั

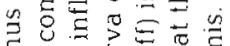

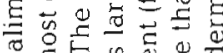
U ป क क $\pi 11=\Xi$ 马े s \& 200

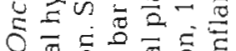
马 đ羊的。 के

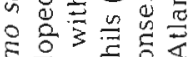
ह ए o 뭉 $\Xi \overline{0}$ $\Xi \nsubseteq$ 为 o 원 우의 क s $\frac{3}{3} \overline{0}$

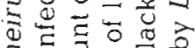
ई 응 $\overline{0}$ 응 투 0

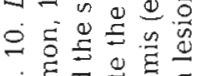

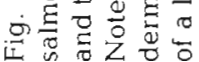




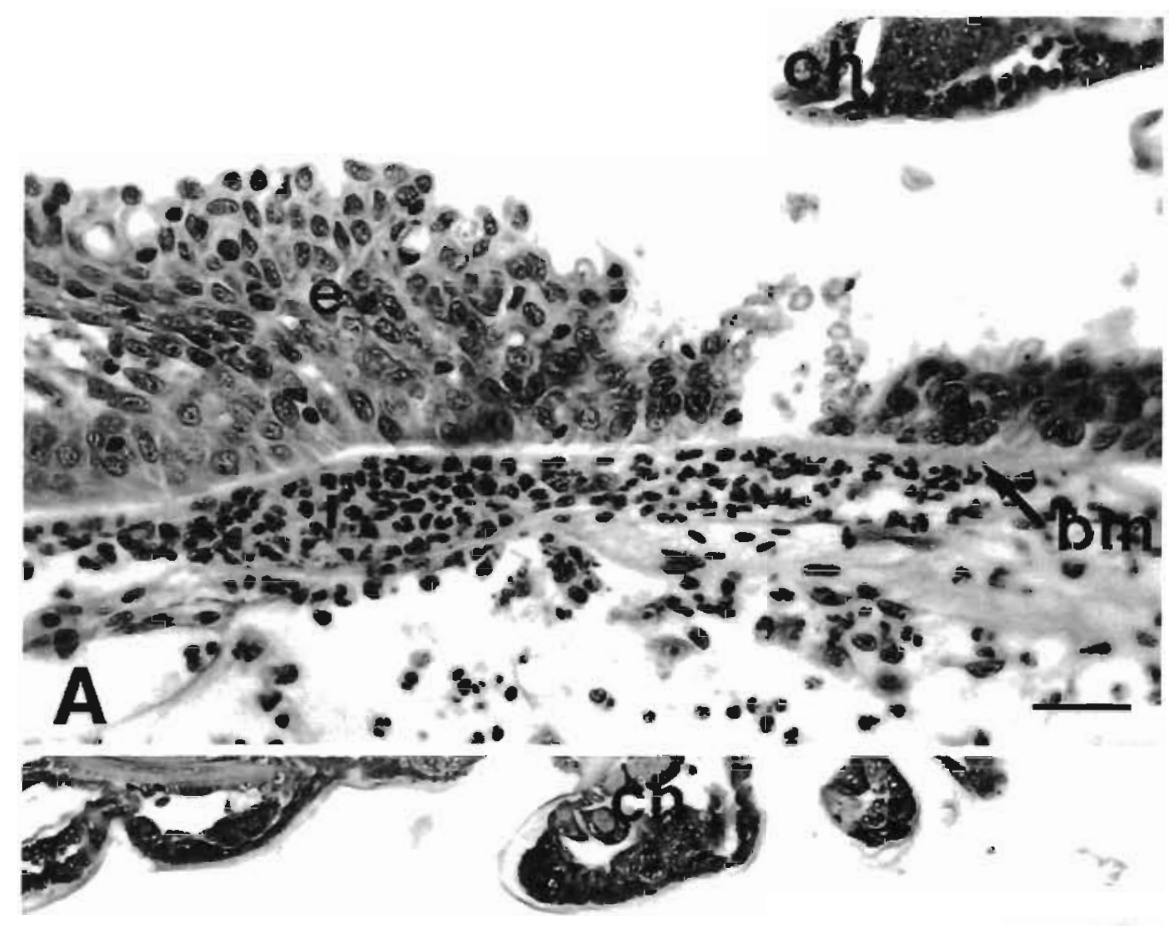

Fig. 11. Lepeophtheirus salmonis infecting Oncorhynchus tshawytscha. Chalimus larvae on fins of chinook salmon. (A) Chalimus larva (ch) on a fin of a chinook salmon, $10 \mathrm{~d}$ postinfection. Note that the epidermis (e) has been breached and that there is a mild inflammatory response. bm: basement membrane; i: mixed inflammatory infiltate. Scale bar = $30 \mu \mathrm{m}$. (B) Chalimus larva on a fin of a chinook salmon, $20 \mathrm{~d}$ post-infection. Note that the epidermis is eroded to the basement membrane, and that there is little inflammatory response. d: dermis; fr: fin ray. Scale bar = $50 \mu \mathrm{m}$

\section{DISCUSSION}

Significant reductions in the intensity of Lepeophtheirus salmonis occurred on all 3 host species over time. These reductions may be caused by active host rejection and/or natural mortality of the copepods independent of any host response. Host rejection of the cyclopoid copepads Lernaea cyprinacea and Lernaea polymorpha has been reported in both naive and previously exposed fish (Shields \& Goode 1978, Shariff \& Roberts 1989, Woo \& Shariff 1990). Rejection of these copepods is believed to be due in part to cellular responses and/or possible physical removal by the fish rubbing their bodies against the tank.

There was no significant difference in the intensity of Lepeophtheirus salmonis between host species early in the experiment. Coho salmon appear to be the most resistant species, having significantly fewer copepods than both chinook or Atlantic salmon at 15 and $20 \mathrm{~d}$ post-infection. Coho salmon have been shown to be more resistant than Atlantic and chinook salmon when both experimentally and naturally exposed to glochidia of the freshwater mussel Margaritifera magaritifera (Myers \& Millemann 1977, Karna \& Millemann 1978).

The intensity data suggest that both chinook and Atlantic salmon share a similar susceptibility to Lepeophtheirus salmonis infection. However, at $20 \mathrm{~d}$ post-infection there was a marked difference in the age structure of $L$. salmonis between the chinook and Atlantic salmon, which suggests that copepods develop at a slower rate on chinook salmon. By the time that an age distribution equal to that seen on the Atlantic salmon is attained on the chinook salmon, the intensity 
Fig. 12. Lepeophtheirus salmonis. Frontal filament structure. (A) Frontal filament of $L$. salmonis chalimus larva, $10 \mathrm{~d}$ post-infection. Note the fibrous stem (s) and the basal plate (bp) attached to the fin ray (fr). Scale bar = $30 \mu \mathrm{m}$. (B) Premolt chalimus larva, 10 d post-infection. Note the presence of a fully formed frontal filament contained within a cuticle-lined pocket in the anterior cephalothorax, and the presence of nuclei (arrow) within the stem of the newly formed filament mc: mouth cone; nc: new cuticle; oc: old cuticle. Scale bar = $50 \mu \mathrm{m}$
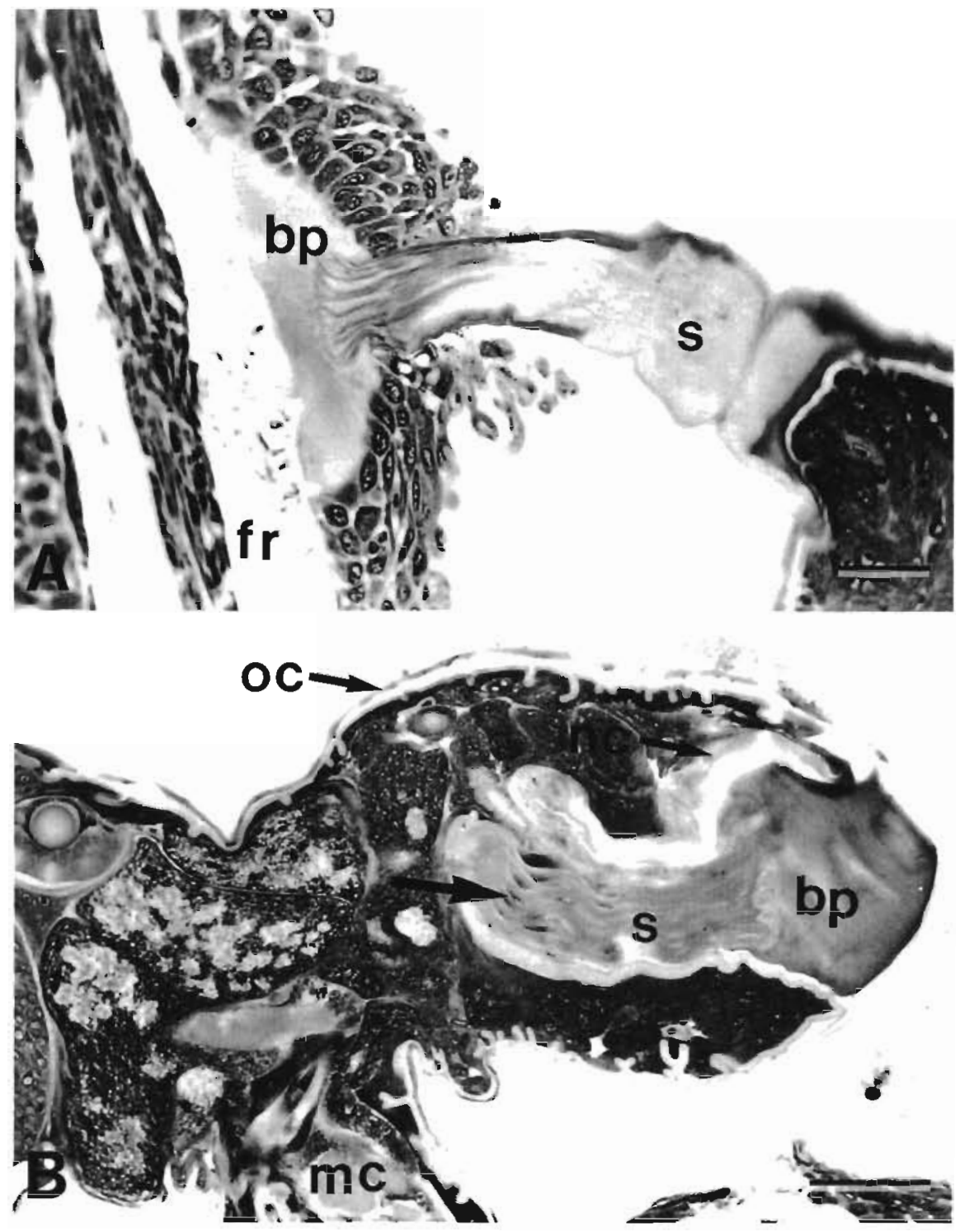

of L. salmonis might be significantly lower. Mortality of L. salmonis or loss from their hosts may be substantial during molting events. Reduced copepod development rates on chinook salmon are in themselves an indicator of lower host susceptibility to $L$. salmonis infection.

We know of no reports of different development rates for a parasite on different animal host species. Differences in the development rates of Lepeophtheirus salmonis between chinook and Atlantic salmon may be caused by nutritional factors and/or nonspecific host defence mechanisms. Fish may produce humoral factors such as growth inhibitors, enzyme inhibitors, and/or substances that interfere with the feeding activities of $L$. salmonis.

Host effects on the biology of parasitic copepods have been previously documented, but the mechanisms are poorly understood. Shariff (1981) suggested that a change in the distribution of Lernaea piscinae growing on big head carp Aristichthys nobilis from the general body to the cornea is a reaction to the development of an immune response within the body of the host; the cornea being an avascular site has a lower level of immune response than the body. Paperna \& Zwerner (1982) reported for Ergasilus labracis growing on stripped bass Morone saxatilis that a welldeveloped tissue response leads to the interruption of parasite egg sac production and an apparent increase in the rate of detachment of the copepods. Woo \& Shariff (1990) reported for Lernaea cyprinacea growing on kissing gourami Helostoma temmincki that a higher proportion of egg sacs are lost from copepods growing on previously exposed fish than naive fish. Furthermore, eggs from copepods growing on previously exposed hosts either fail to develop or produce 
copepodids that have a low infectivity when compared to copepodids hatched from eggs of copepods growing on naive hosts.

The presence of earlier developmental stages on the gills of Atlantic salmon when compared with the fins and body surfaces further supports the hypothesis that non-specific humoral factors may be affecting the development rate of Lepeophtheirus salmonis. The gills, as they are highly vascularized in comparison to the fins and body, should have a more pronounced immune response. Blood was found in the guts of all copepods feeding on the gills, whereas blood was found less commonly in the guts of copepods feeding on the fins and general body surfaces. Differences in the development rate of $L$. salmonis on different body regions of Atlantic salmon may explain the large range of variability in development rates reported between individual copepods by Johnson \& Albright (1991b).

One criticism of this study's experimental design is that the free moving preadult stage may have migrated from the chinook to the Atlantic salmon causing the observed difference in the age class distribution. We would argue that this is unlikely as we would expect a proportion of the preadults that matured on the chinook to remain attached by their frontal filament. Approximately $63 \%$ of the first preadults found on Atlantic salmon had retained their frontal filaments. Retention of the frontal filament by the first preadult stage is commonly reported in many species of caligid copepods from a wide variety of hosts (Johnson \& Albright 1991a).

Early in the experiment, high percentages of the copepodites on all host species became detached and were found swimming in the anesthetic bath. This suggests that settlement may be reversible up to the first chalimus molt and that the copepodites may change position on the host. This ability to change position may explain the wide variation in the severity of lesions caused by the copepodid stage in this study. Migration after settlement from the general body surfaces to the fins has been reported for the copepodites of Lernaeenicus sprattae (Anstensrud \& Schram 1988).

In our experiment copepods were recovered from the gills of all 3 host species. The presence of Lepeophtheirus salmonis on the gills of laboratory-infected Atlantic salmon has been previously reported (Bron et al. 1991). These authors suggest that copepods may settle on the gills of tank-maintained fish due to slower current through the buccal cavity when compared to wild or pen-reared fish. Although $L$. salmonis has not been reported on the gills of pen-reared salmonids, both copepodids and chalimus stages have been found on the gills of mature wild sockeye salmon in British Columbia (pers. obs.).

The elimination of copepods from the gills of coho salmon by $10 \mathrm{~d}$ post-infection was possibly due to the well-developed inflammatory responses. Glochidia of the freshwater mussel Margaritifera margaritifera have been reported to be sloughed from the gills of coho salmon by $4.5 \mathrm{~d}$ post-infection at $12^{\circ} \mathrm{C}$ by welldeveloped epithelial hyperplasias (Fustish \& Millemann 1978).

The distribution of Lepeophtheirus salmonis on Atlantic salmon at $10 \mathrm{~d}$ post-infection is similar to that reported by Bron et al. (1991) for early chalimus stages on experimentally infected Atlantic salmon. In their study, $69 \%$ of the copepods were recovered from the fins, $21 \%$ from the gills, and $18 \%$ from the body. These authors suggested that distribution is principally a question of local current speed and the ability of the copepodids to hold on in any given area. The results of the present study indicate that other factors such as differences between tissues in their response to L. salmonis are important in determining the distribution on the body.

The extent of tissue damage and the magnitude of the host response were highly variable on all 3 host species over the period of 1 to $5 \mathrm{~d}$ post-infection. Over this period the majority of Lepeophtheirus salmonis was present as free-moving copepodid larvae. Movement of the copepodids on the host would explain this high variability. Copepodids may change positions to locate a suitable site for frontal filament attachment, and/or to avoid host tissue reactions.

Intense reactions of coho gill tissue to the presence of parasitic organisms, as observed in the present study, have been previously documented. These reactions include epithelial hyperplasia, fusion of the secondary gill lamellae, and severe inflammatory responses (Fustisch \& Millemann 1978, Kent et al. 1989).

The gill tissue responses of both chinook and Atlantic salmon are similar to those reported for other host species infected with other species of parasitic copepods. Previously reported responses include: hyperplasia resulting in the loss of lamellar structure (Kabata 1970, Kabata \& Cousens 1977, Paperna \& Zwerner 1982), proliferation of mucous cells within the hyperplastic epithelium (Paperna \& Zwerner 1982), hypertrophy of the epithelial cells (Kabata \& Cousens 1977), and extensive infiltration of macrophages, lymphocytes and eosinophils into heavily infected gills (Paperna \& Zwerner 1982).

The inflammatory response of the gills of chinook salmon seen in this study is similar to the chronic inflammatory response described for the gills of mature chinook salmon infested with the fungus Dermocystidium sp. (Pauley 1967). This author reports that the inflammatory response was characterized by infiltration of lymphocytes, monocytes, macrophages and granulocytes. 
Differences between coho and chinook salmon with respect to the intensity of their gill tissue reactions to parasitic infection have been previously reported. Gills of chinook salmon exposed to Margaritifera margaritifera showed only mild hyperplastic and inflammatory responses when compared to gills of coho salmon, which showed well-developed hyperplastic and inflammatory responses as well as fusion of the secondary gill lamellae (Fustisch \& Millemann 1978).

From $10 \mathrm{~d}$ post-infection through to the end of the experiment, attachment and feeding sites on the fins of coho salmon were characterized by extensive epithelial hyperplasias and well-developed inflammatory responses. Over the same period, attachment and feeding sites on the fins of chinook and Atlantic salmon were characterized by extensive epithelial erosion and mild inflammatory responses. The well-developed tissue responses of coho salmon may be responsible for their greater resistance to Lepeophtheirus salmonis.

The intensity of the tissue response reported for fins of Atlantic salmon in the present study is similar to that reported for the general body surfaces of Atlantic salmon infected with Lepeophtheirus salmonis chalimus larvae (Jones et al. 1990). These authors reported erosion of the epidermis in the vicinity of the mouth cone, the lack of a dermal reaction, and a normal or mildly hyperplastic epithelium in the vicinity of the frontal filament. Boxshall (1977) reported on the histopathology of lesions on the fins of naturally infected flounder Platichthys flesus caused by the closely related copepod species Lepeophtheirus pectoralis. Damage to the fins was usually confined to the epidermis and little response to the presence of the copepod was seen unless the dermis was breached. In cases where the dermis was breached, an inflammatory response, comprised of fibroplasia and cellular infiltration, occurred and resulted in the formation of a dense fibrous granulation tissue.

In our study the rejection of Lepeophtheirus salmonis by naive hosts was most likely due to a nonspecific immune response. However, we cannot rule out the possibility that some specific immunity may have developed towards the end of the experiment and contributed to the rejection of $L$. salmonis. Grayson et al. (1991) report that naturally infected Atlantic salmon mount a low-level specific antibody response to antigens associated with the gut epidermis of $L$. salmonis.

The mechanisms by which the non-specific immune system rejects Lepeophtheirus salmonis remain to be determined. Both normal and activated macrophages of rainbow trout have been shown to have larvicidal activity against the eye fluke Diplostonum spathaceum, but the mechanisms of this activity are unknown (Whyte et al. 1989).
Neutrophils were the predominant cells at sites of inflammation in all 3 host species that were investigated. Macrophages were common at sites of inflammation of the fins of coho salmon from $10 \mathrm{~d}$ postinfection onwards. Both neutrophils and macrophages are the predominant cell types reported at sites of inflammation of a wide variety of both naive and previously exposed fish hosts infected with parasitic copepods (Joy \& Jones 1973, Boxshall 1977. Shields \& Goode 1978, Shariff 1981, Paperna \& Zwerner 1982, Shariff \& Roberts 1989). Lymphocytes were present at sites of inflammation in our experimental fish only in very low numbers. This suggests that cell-mediated immunity does not play a major role in the elimination of Lepeophtheirus salmonis from these hosts.

The structure of the attached frontal filament is identical to that reported by Bron et al. (1991) for Lepeophtheirus salmonis. The fully formed frontal filaments seen in the anterior cephalothorax of premolt chalimus larvae have not been previously reported. Although fully formed frontal filaments have been reported in the copepodid stage of a wide variety of parasitic copepods (Wilson 1911, Gurney 1934, Hwa 1965, Kabata 1972,1976 ), no frontal filament was reported in newly molted copepodids of $L$. salmonis (Johnson \& Albright 1991a). It is possible that fully formed frontal filaments are only present in late copepodid larvae immediately preceding the molt. Johnson \& Albright (1991a), as well as others, may have missed reporting the presence of the frontal filament in the copepodid stage by describing copepodids too early in their development.

The current belief is that Lepeophtheirus salmonis attaches to its host using a glue-like secretion. This gluelike secretion is thought to be injected beneath the epidermis where it spreads out laterally along the basement membrane to form the 'basal plate' of the frontal filament (see Bron et al. 1991). It is also reported that L. salmonis remains attached by its original frontal filament throughout its development (see Jones et al. 1990).

In the present study, 'reservoirs of filament material' were commonly seen in both the copepodid and chalimus stages of Lepeophtheirus salmonis. These structures have been previously reported in both the copepodid and chalimus stages of $L$. salmonis (Bron et al. 1991). It is our belief that these 'reservoirs of filament material' are in fact new frontal filaments in early stages of development. As suggested for the copepodid stage, fully formed frontal filaments may be present in chalimus larvae only immediately preceding the molt. The cuticle-lined pocket seen surrounding the filament in this study suggests that both the filament and the anterior region of the cephalothorax are pulled out prior to hardening of the new cuticle. Material which functions as a glue may be secreted via the axial duct and serves to attach the basal plate to the host. 
In summary, naive coho salmon appear to be the most resistant species to experimental infection with Lepeophtheirus salmonis, with all copepods lost from the gills by $10 \mathrm{~d}$ post-infection and only a few remaining on the fins at $20 \mathrm{~d}$ post-infection. Rejection of L. salmonis on all 3 host species is most likely due to non-specific host responses. In coho salmon these responses include well-developed epithelial hyperplasias and inflammatory responses. The response of chinook salmon to $L$. salmonis appears to be intermediate in intensity between that of the coho and Atlantic salmon. Little response to the presence of $L$. salmonis was observed in Atlantic salmon. The developmental rate of $L$. salmonis appears to be higher on Atlantic salmon than chinook salmon. The developmental rate of $L$. salmonis on both chinook and Atlantic salmon may be mediated by some form of host response. The presence of fully formed frontal filaments in premolt chalimus larvae indicates that further investigations into the mechanism and timing of filament production are required.

Acknowledgements. We thank Dr L. Margolis for critically reviewing this manuscript. This research was funded by the Department of Fisheries and Ocean's Biological Sciences Branch, Pacific Region, and a by a Natural Sciences and Engineering Research Council of Canada Operating Grant to L.J.A. S.C.J. was supported by a British Columbia Science Council GREAT scholarship.

\section{LITERATURE CITED}

Anstensrud, M., Schram, T A. (1988). Host and site selection by larval stages of adults of the parasitic copepod Lernaeenicus sprattae (Sowerby) (Copepoda, Pennellidae) in the Oslofjord. In: Boxshall, G. A., Schminke, H. K. (eds.) Biology of copepods. Hydrobiologia 167/168: 587-595

Boxshall, G. A. (1977). The histopathology of infection by Lepeophtheirus pectoralis (Muller) (Copepoda: Caligidae) J. Fish Biol. 10: 411-415

Brandal, P. O., Egidius, E. (1979). Treatment of salmon lice (Lepeophtheirus salmonis Krøyer, 1838) with Neguvon ${ }^{\mathrm{R}}$ description of method and equipment. Aquaculture 18 : $183-188$

Brandal, P. O., Egidius, E., Romslo, I. (1976). Host blood: a major food component for the parasitic copepod Lepeophtheirus salmonis Kroyer, 1838 (Crustacea: Caligidae) Norw. J. Zool. 24: 341-343

Bron, J. E., Sommerville C., Jones, M., Rae, G. H. (1991). The settlement and attachment of early stages of the salmon louse Lepeophtheirus salmonis (Copepoda: Caligidae) on the salmon host, Salmo salar. J. Zool., Lond. 224: 201-212

Fustısh, C. A., Millemann, R. E. (1.978). Glochidiosis of salmonid fishes. II. Comparison of tissue response of coho and chinook salmon to experimental infection with Margaritfera margaritıfera (L.) (Pelecypoda: Margantanidae). J. Parasitol. 64: 155-157

Grayson, T. H., Jenkins, P. G., Wrathmell, A. B., Harris, J. E. 1991). Serum responses to the salmon louse Lepeophtheirus salmonis (Kroyer, 1883), in naturally infected salmonids and immunized rainbow trout, Oncorhynchus mykiss (Walbaum), and rabbits. Fish Shellfish Immunol. 1. $141-155$

Gurney, R. (1934). The development of certain parasitic Copepoda of the families Caligidae and Clavellidae. Proc. zool. Soc. Lond. 12:177-217

Hwa, T.-K. (1965). Studies on the life history of a fish louse (Caligus orientalis Gussev). Acta zool. sin. 17.48-57 (in Chinese with English summary)

Johnson, S. C., Albright, L. J (1991a). The developmental slages of Lepeophtheirus salmonis (Krøyer. 1837) (Copepoda: Caligidae). Can. J. Zool. 69: 929-950

Johnson, S. ( $\therefore$, Albright, L. J. (1991b). Development, growth, and survival of Lepeophtheirus salmonis (Copepoda: Caligidael under laboratory conditions. J. mar. biol. Ass. U.K. $71: 425-436$

Jones, M. W., Sommerville, C., Bron, J. (1990). The histopathology associated with the juvenile stages of Lepeophtheirus salmonis on the Atlantic salmon, Salmo salar L. J. Fish Dis. 13: 303-310

Joy, J. E., Jones, L. P. (1973). Observations on the inflammatory response within the dermis of a white bass, Morone chrysops (Rafinesque), infected with Lernaea cruciata (Copepodd: Caligidde). J. Fish Biol. 5: 21-23

Kabata, Z. (1970). Crustacea as enemies of fishes. In: Snieszko, S. F., Axelrod, H. R. (eds.) Diseases of fishes. Book 1 TFH Publications, Jersey City

Kabata, Z. (1972). Developmental stages of Caligus clemens (Copepoda: Caligidae). J. Fish. Res. Bd Can. 29: 1571-1593

Kabata, Z. (1974). Mouth and mode of feeding of Caligidae (Copepoda), parasites of fishes, as determined by light and scanning electron microscopy. J. Fish. Res. Bd Can. 31: $1583-1588$

Kabata, Z. (1976). Early stages of some copepods (Crustacea) parasitic on marine fishes of British Columbia. J. Fish. Res. Bd Can. 33: 2507-2525

Kabata, Z. (1979). Parasitic Copepoda of British fishes. The Ray Society, London

Kabata, Z. (1988). Copepoda and Branchiura. In: Margolis, L. Kabata, Z. (eds.) Guide to the parasites of fishes of Canada. Part II - Crustacea. Can. Spec. Pub. Fish. Aquat. Sci. 101: 3-127

Kabata, Z., Cousens, B. (1977). Host-parasite relationships between sockeye salmon, Oncorhynchus nerka, and Salmincola californiensis (Copepoda: Lernaeopodidae). J. Fish. Res. Bd Can. 34: 191-202

Karna, D. W., Millemann, R. E. (1978). Glochidiosis of salmonid fishes. III. Comparative susceptibility to natural infection with Margaritifera margaritifera (L.) (Pelecypoda: Margaritanidael and associated histopathology. J. Parasitol. 64: 528-537

Kent, M. L., Elliott, D. G., Groff, J. M., Hedrick, R. P. (1989). Loma salmonae (Protozoa: Microspora) infections in seawater reared coho salmon Oncorhynchus kisutch. Aquaculture 80: 211-222

Myers, T. R. Millemann, R. E. (1977). Glochidiosis of salmonıd fishes. I. Comparative susceptibility to experimental infection with Margaritifera magaritifera (L.) (Pelecypoda: Margaritanidae). J. Parasitol. 63: 728-733

Nagasawa, K. (1987). Prevalence and abundance of Lepeophtherrus salmonis (Copepoda: Caligidae) on highseas salmon and trout in the North Pacific Ocean. Nippon Suisan Gakk. 53: 2151-2156

Nagasawa, K. Ishida, Y., Tadokoro, K. (1991). Occurrence of salmon lice Lepeophtherrus salmonus on longline-caught salmon in the North Pacific Ocean and Bering Sea in the summer of 1991 Submitted to the Annual Meeting of the 
International North Pacific Fisheries Commission, Tokyo, Japan, October 1991 National Research Institute of Far Sea Fisheries, Fisheries Agency of Japan, Shimizu, Shizuoka 424, Japan

Paperna, 1., Zwerner, D. E. (1982). Host-parasite relationship of Ergasilus labracis Kroyer (Cyclopidea, Ergasilidae) and the striped bass, Morone saxatilis (Walbaum) from the lower Chesapeake Bay. Annls Parasit. hum comp. 57: 393-405

Pauley, G.B. (1967). Prespawning adult mortality associated with a fungus of the genus Dermocystidium. J. Fish. Res. Bd Can. 24:843-848

Pike, A. W. (1989). Sea lice - major pathogens of farmed Atlantic salmon. Parasitol. Today 5: 291-297

Shariff, M. (1981). The histopathology of the eye of big head carp, Aristichthys noblis (sic.) (Richardson), infested with Lernaea piscinae Harding, 1950. J. Fish Dis. 4: 161-168

Shariff, M., Roberts, R. (1989). The experimental histopathology of Lernaea polymorpha Yu, 1938 infection in naive Aristichthys nobilis (Richardson) and a comparison with the lesion on naturally infected clinically resistant

Responsible Subject Editor: W. Körting, Hannover, Germany fish. J. Fish Dis. 12: 405-414

Shields, R. J., Goode, R. P. (1978). Host rejection of Lernaea cyprinacea L. (Copepoda). Crustaceana 35: 301-307

Whyte, S. K. Chappell, L. H., Secombes, C. J. (1989). Cytotoxic reactions of rainbow trout, Salmo gairdnert Richardson, macrophages for larvae of the eye fluke Diplostomum spathaceum (Digenea). J. Fish Biol. 35: $333-345$

Wilson, C. B. (1911). North American parasitic copepods. Part 9. The Lernaeopodidae. Proc. U.S. natl Mus. 39: $189-266$

Woo, P. T K., Shariff, M. (1990). Lernea cyprinacea L. (Copeoda: Caligidae) in Helostoma temmincki Cuvier \& Valenciennes: the dynamics of resistance in recovered and naive fish. J. Fish Dis. 13: 485-493

Wootten, R., Smith, J. W., Needham, E. A. (1982). Aspects of the biology of the parasitic copepods Lepeophtheirus salmonis and Caligus elongatus on farmed salmonids, and their treatment. Proc. R. Soc. Edinb. (Sect. B) 81: 185-197

Zar, J. H. (1984). Biostatistical analysis. Prentice Hall, Englewood Cliffs

Manuscript first received: March 19, 1992

Revised version accepted: August 8, 1992 